\title{
Asterias rubens (Echinoderm): Evidence of Lymphocytes, Lymphokines and Invertebrate Primitive antibody
}

\author{
Michel Leclerc \\ 556 rue Isabelle Romée, 45640 Sandillon (France) \\ *Corresponding Author: Michel Leclerc, 556 rue Isabelle Romée, 45640 Sandillon (France)
}

\begin{abstract}
The axial organ is considered as ancestral lymphoïd organ. It contains $T$ and B sea star lymphocytes and Phagocytes. It plays a fundamental rôle in the sea star cell-mediated immune responses and humoral immune ones.Asterids belong to Echinoderma.
\end{abstract}

\section{ECHINODERMA}

The position of the echinoderms, in particular, has been a matter of doubt and controversy in the studies of the vertebrate ancestors.

Embryological, anatomical and biochemical evidence seem now to indicate that the first one is wrong: echinoderms, as proposed Kampmeier (ref1), are more likely to have been the ancestors of the invertebrates than the annelids.

An essential point appears to be the fact that echinoderms are deuterostomia, like the vertebrates, while annelids are protostomia, like arthropods and mollusks.

In the ontogeny of protostomia, the « blastopore» becomes the mouth; in the deuterostomia, on the contrary, the anus arises from the blastopore, the mouth being a new acquisition.

It must also be remarked that although, in the phylum Echinodermata, the adult animal has a radial symetry, the larva is bilateral.

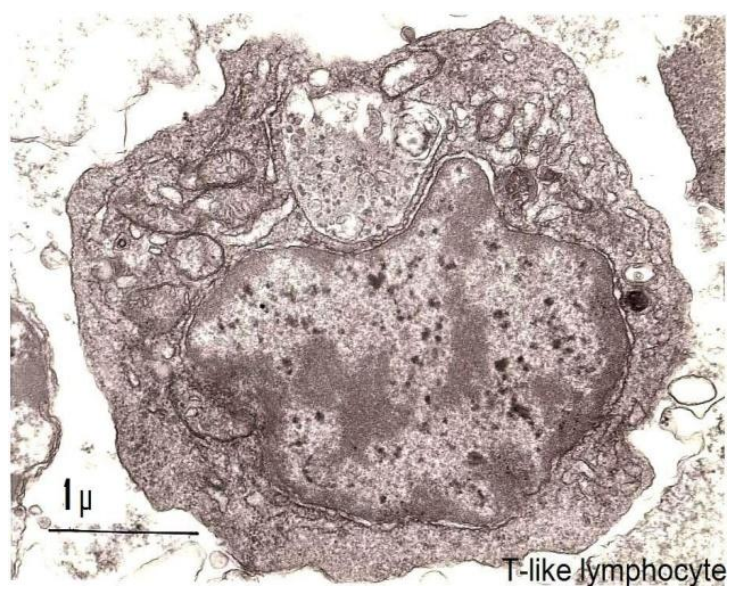

Figure 1
The SEA-STAR LyMPHOCYTES From ASTERIAS RUBENS.

Sea-stars belong to the class Asteroidea of the phylum Echinoderma.

They are marine animals, also named starfishes. They possess a primitive lymphoïd organ :

The axial organ which lies along the stone canal.

The structure of the axial organ is glandular, spongy and crossed by connective tissue.

Many follicles of heterogeneous size with clear zones are lined by cellular cords.

The various types of cells present in the axial organ have been studied in our laboratory, by optical and electron microscopy (S.E.M and T.E.M).

Essentially two types of cells are found in T.E.M ( ref 2) :

Cells which morphologically resemble mammal lymphocytes ( Fig.1) (Fig .2).

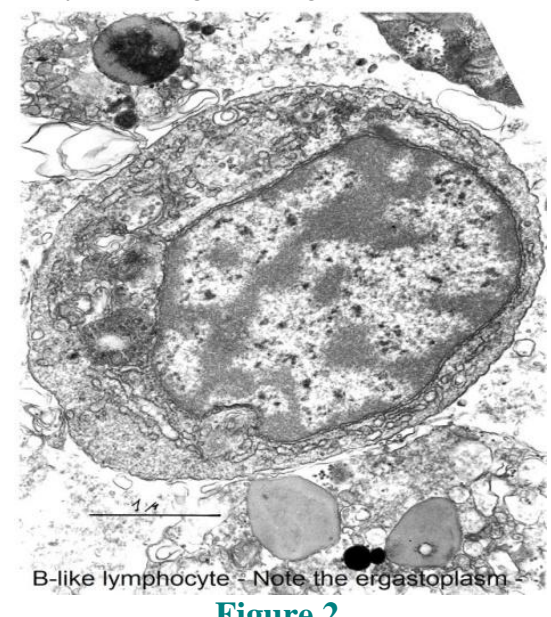

Figure 2 
Asterias rubens (Echinoderm): Evidence of Lymphocytes, Lymphokines and Invertebrate Primitive antibody

Cells which are phagocytes. (Fig.3)

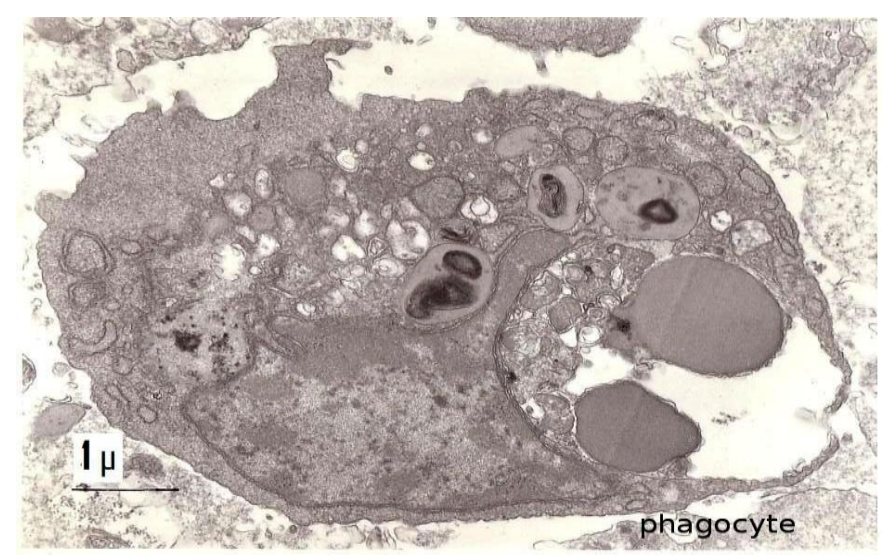

Figure 3

\section{LYMPHOKINES}

The method of Leiper and Solomon (ref 3) was used, with some modifications.Cells were separated by nylon wool and were cultured for $24 \mathrm{~h}$ at $10^{\circ} \mathrm{C}$ in the presence of PWM-coated Sepharose beads. Supernatants from these cultures were centrifuged to eliminate beads and debris, sterilized by membrane filtration ( 0.22 $\mu \mathrm{m}$ Millipore) and concentrated 5- or 10-fold with an ultrafiltration device (Amicon) fitted with «PM-10 Diaflo» membranes. Supernatant controls were obtained from cells cultured with non-coated beads, from cells cultured alone and from beads cultured alone. The supernatants were added to cultures of total axial organ cells which had been started $24 \mathrm{~h}$ before, and $24 \mathrm{~h}$ later, the cells were harvested and mitogenic stimulation was evaluated by measuring tritiated-H-methyl- thymidine incorporation.

It was found that the the supernatant from the non-adherent cells cultured in the presence of PWM beads stimulated the total axial organ cells. No stimulation was observed in the various controls. This result indicates that nonadherent cells(i-e sea star $\mathrm{T}$ lymphocytes) produce a lymphokine mediator which is able to stimulate the total axial organ cells. The active substance was inactivated by trypsin and chemotrypsin, or by heating for $1 \mathrm{~h}$ at $70^{\circ} \mathrm{C}$, but it resisted at $56^{\circ} \mathrm{C}$. (ref 4$)$

In 1997, cytokines and cytokine-receptors were discovered indirectly by the use of Cytofluorometry (ref 5) and genomic studies ( ref. 6)

\section{HUMORAL RESPONSES: IPA (InVERTEBrate Primitive Antibody}

In a first study(Leclerc, 1973, ref 7), it was shown that the Asterina gibbosa axial organ cells, previously injected with horse-radish peroxydase(HRP) were able to react specifically with the same enzyme. This observation was made by T.E.M, using an immunocytochemical technique.A similar result was later observed with the Asterid: Asterias rubens. Since a variety of antigens, were injected in the coelomic cavity, near the axial organ of Asterids, such as : E.coli alkaline phosphatase, bovine serum albumin, rat IgG, human lambda Bence-Jones protein, myoglobin, and more recently, the haptens : TNP and FITC coupled to polyacrylamide beads . Results were summarized in 2012 (ref.8) We identified an invertebrate primitive antibody, characteristics of which were: specificity and structure $(2 \mathrm{Ig}$ sites) after its(sea star) immunization to HRP and genomic research( ref 9 ): The gene showed a specific immune response to the enzyme HRP after its insertion in an Escherichia coli plasmid (ref 10).Moreover $\mathrm{Fab}$ gene, $\mathrm{Fc}$ receptor gene, $\mathrm{Cr}$ gene and MHC genes were recently discovered

\section{CONCLUSIONS}

The general idea that emerges from the experiments reported in the present review is that Echinoderma, as exemplified by the sea star: Asterias rubens, possess an ancestral lymphoïd organ: the axial organ. It appears that all the elements necessary to immune responses ( phagocytic cells, T sea star lymphocytes, B lymphocytes,) are present in this organ which initiates: lymphokines, humoral immune responses (invertebrate primitive antibody: IPA) of the sea star.

\section{REFERENCES}

[1] Kampmeier, O.F.,Evolution and comparative morphology of the lymphatic system(1969) p.72 in Charles C. Thomas, Springfield. 
Asterias rubens (Echinoderm): Evidence of Lymphocytes, Lymphokines and Invertebrate Primitive antibody

[2] Anteunis,A., Leclerc, M.,Vial, M., et al., Cell. Biol. Int.Rep.(1985),9, 663.

[3] Leiper,J.B., Solomon,J.B., Immunology (1977), $32,215-226$.

[4] Leclerc, M., Brillouet, C.,Luquet, G., et al. Scand. J.Immunol.(1981),14,281-284.

[5] Legac, E., Vaugier,G.L., Bousquet,F., et al. Scand.J. Immunol. (1997), 44,375-380.
[6] Leclerc,M.Amer.J.Immunol (2012) 8(3) , 78-83

[7] Leclerc,M. Ann. Immunol (1973) 124(3) ,363-74

[8] Leclerc,M. Amer.J.Immun.,(2012) 4, 196-199.

[9] Vincent,N., Osteras, M., et al Metagene(2014) $2,320-322$

[10] Leclerc, M., and Otten ,P SAJ Biotechnology (2014), 1, 1-3

Citation: Michel Leclerc, “Asterias rubens (Echinoderm): Evidence of Lymphocytes, Lymphokines and Invertebrate Primitive antibody”, International Journal of Research Studies in Medical and Health Sciences. 2020; 5(2): 29-31.

Copyright: (c) 2020 Michel Leclerc, This is an open-access article distributed under the terms of the Creative Commons Attribution License, which permits unrestricted use, distribution, and reproduction in any medium, provided the original author and source are credited. 